\title{
1 OLITICAL INSTABILITY AND CORRUPTION. THE PHANARIOT REGIME AS SEEN BY RUSSIAN AND NORDIC TRAVELLERS
}

\section{Mihaela Mehedinti-Beiean}

Babeş-Bolyai University, Romania, E-mail: mihaela_mehedinti@yahoo.com

\section{Acknowledgements}

This paper was presented at the Seventh annual international conference on Baltic and Nordic Studies in Romania. Good governance in Romania and the Nordic and Baltic countries, hosted by the Romanian Association for Baltic and Nordic Studies and „Nicolae Iorga” Institute of History of the Romanian Academy, November 24$25,2016$.

\begin{abstract}
:
The history of the Romanian Principalities was particularly tumultuous during the modern period, given that they were situated in a geographical area of great interest for three large empires: the Ottoman Empire, the Austrian Monarchy and Russia. As a result, the political regime established in Moldavia and Wallachia in the 18th century and which lasted until 1821 bore all the hallmarks of Orientalism as expressed by rulers, namely the most profound corruption at all administrative levels, an utter lack of interest regarding the people's welfare and the unremorseful pursuit of their own interests.

The Nordic and Russian travellers were acutely aware of all these problems and considered that the Ottomans were the only ones to blame for this deplorable state of affairs. Unfortunately, with time, some of the shortcomings associated with the Phanariot regime became unmistakable traits of Romanian political behaviour which persisted well into the 20th century. Nevertheless, some of the travellers also remarked the adoption of a number of reforms with highly beneficial effects for the Principalities between 1711/1716 and 1821 and, at least apparently, the period when General Pavel Kiseleff was governor of Moldavia and Wallachia was an especially prolific one in terms of reversing some of the damage caused by the Phanariots.

However, one of the limitations of using travel literature as a source is that it needs to be treated with extreme care when it comes to establishing the boundaries between truth and fiction, as well as between innocent observations and decidedly dishonest interpretations. The aim of the present study is thus to present all of the above-
\end{abstract}


mentioned political evolutions as they were seen by foreign travellers, whilst also questioning and unravelling the latter's motives for depicting a certain image of the Romanian Principalities' political elite.

\section{Rezumat:}

Istoria Principatelor Române a fost deosebit de tumultoasă în perioada modernă, dat fiind că erau situate într-o zonă geografică de un interes major pentru trei mari imperii: Imperiul Otoman, Monarhia Austriacă şi Rusia. Drept urmare, regimul politic instaurat în Moldova şi Muntenia în secolul al XVIII-lea şi care a durat până la 1821 purta toate semnele orientalismului exprimat de domnitori, mai exact cea mai profundă corupție la toate nivelurile administrative, o completă lipsă de interes față de bunăstarea poporului şi urmărirea fără remuşcări a propriilor interese.

Călătorii nordici şi ruşi au fost perfect conştienți de aceste probleme, considerând că otomanii erau unicii vinovați pentru această deplorabilă stare de lucruri. Din păcate, in timp, unele dintre defectele asociate regimului fanariot au devenit trăsături inconfundabile ale comportamentului politic românesc care au persistat până în secolul XX. Cu toate acestea, unii dintre călători au remarcat şi adoptarea unui număr de reforme cu efecte foarte benefice pentru Principate intre 1711/1716 şi 1821 şi, cel puțin in aparență, perioada în care Generalul Pavel Kiseleff a fost guvernatorul Moldovei şi Munteniei a fost una extrem de prolifică în ceea ce priveşte anularea unora dintre daunele cauzate de fanarioți.

Totuşi, una dintre limitările utilizării literaturii de călătorie ca sursă este că e nevoie să fie tratată cu maximă grijă atunci când vine vorba de stabilirea granițelor dintre adevăr şi ficțiune sau dintre observațiile inocente şi interpretările indiscutabil false. Scopul prezentului studiu este astfel de a prezenta toate evoluțiile politice menționate mai sus în maniera în care au fost văzute de călătorii străini, chestionând şi scoțând in evidență în acelaşi timp motivele acestora pentru a prezenta o anumită image a elitei politice din Principatele Române.

Keywords: Phanariot regime, Romanian Principalities, political history, travel literature, 18th-19th centuries

\section{Introductory aspects}

Moldavia and Wallachia, also known as the Romanian Principalities, had a turbulent modern history that was mainly due to the fact that they were situated within the sphere of influence of several large empires. ${ }^{1}$ Within

1 Details about the political evolutions of the area in the $17^{\text {th }}-18^{\text {th }}$ centuries are available in Mihai Maxim, $O$ istorie a relațiilor româno-otomane, cu documente noi din arhivele turceşti. Vol. II: De la Mihai Viteazul la fanarioți (1601-1711/1716) (Brăila: Editura Istros a Muzeului Brăilei, 
this context, the beginning of the $18^{\text {th }}$ century brought about an intensification of the Ottoman pressure in the area that resulted in the establishment of what was to be labelled by historiography as the Phanariot regime. ${ }^{2}$ Thus, starting with 1711 for Moldavia and 1716 for Wallachia ${ }^{3}$ the rulers of the two principalities became members of the Ottoman Empire's administration, being regarded as high officials who were equivalent to a pasha with two horsetails ${ }^{4}$ and were appointed by the Sultan in accordance with his own interests and with the sums of money offered by the future rulers.

As a result, most historians regard the inauguration of the Phanariot regime as a means by which the Porte intended to strengthen its political, military, economic, financial, social and cultural control over the Romanian Principalities, given that it had significant strategic interests in the area. Consequently, the replacement of local rulers with mostly Greek ones inhabiting one of Constantinople's neighbourhoods, namely Fanar/Fener (hence the designation of the princes and, by extension, of the regime), was accomplished so that the new princes were aware of their most important assignments: "fulfilling the various obligations of the Romanian Principalities towards Istanbul, consolidating the Ottoman domination north of the inferior Danube, limiting the power and opposition of the Romanian-Levantine boyar class, modernising the Romanian political, administrative, financial, social, economic structures, through the adoption of adequate reforms, in order to adapt them to an efficient exploitation in the benefit of the Ottoman Porte" .5

2013), pp. 18-56, the author's pertinent and detailed analysis regarding the Ottoman Empire's both external and internal politics.

2 Other synonymous phrases are "Phanariot period", "Phanariot century" and "Phanariot rule".

${ }^{3}$ In reality, as Mihai T,ipău, Domnii fanarioți în Țările Române 1711-1821. Mică enciclopedie (Bucharest: Omonia, 2004), p. 9 points out, this chronological limit was not that obvious for contemporaries, the 1711/1716-1821 timeframe being set later on by historians.

4 Nicolae Zaharia, Educație şi cultură în secolul fanariot (Câmpulung Muscel: Larisa, 2012), p. 17.

${ }^{5}$ Maxim 2013, pp. 434-435. Vasile-Mihai Olaru also supports this view: "The period under study [namely 1775-1831], corresponding to the last phase of the Phanariot period and the 'indigenous princes' (domniile pământene), scattered with military occupations by Russian, Austrian and Ottoman troops, is hardly regarded as a period of modernization or development. Without constituting an object of analysis, the state was considered to consist of the body of venal officials, corrupt, inefficient and usually abusive in their relations with the common subjects. It was also the period when the Wallachia (like Moldavia) lacked an army and sovereignty, playing the role of temporary provider for various occupation armies"; 
This epoch which lasted until 1821 was characterised by extreme political instability, a marker of Orientalism recognised as such by most foreign travellers. ${ }^{6}$ Hence, during 1711/1716-1821 the political regime from the Principalities bore all the hallmarks of bad governance: ${ }^{7}$ omnipresent corruption, disregard towards the people, decisions and actions that were aimed at enriching the ruling elite, bureaucratisation. ${ }^{8}$ Although some progress in terms of culture, education and even legislation was also noticeable (and noted by some travellers), it did not alter the overall negative picture of the Phanariot century, as the following pages will demonstrate.

Although the concept of governance is mostly present in the works of sociologists, political analysts and economists, historians can also make good use of it, despite the perils associated with applying modern terms to

Vasile-Mihai Olaru, 'The Princely Fathom. Uniformization of Measures and State Making in Wallachia, 1775-1831', Studia Universitatis Babeş-Bolyai, Historia, Vol. 60, No. 1 (2015b): 204.

6 A very useful summary of foreign travellers' notes on the Phanariot period was accomplished by Liviu Popescu, "Imaginea regimului politic în Principate. De la fanarioți la mişcarea lui Tudor Vladimirescu", in Societatea românească între modern şi exotic văzută de călători străini (1800-1847), eds. Ileana Căzan, Irina Gavrilă (Bucharest: Oscar Print, 2005), pp. 27-92, many of the elements emphasised by the author being also present in the notes pertaining to Russian and Nordic voyagers. For example, I agree with Liviu Popescu's affirmation that "Sketching short portraits of the Phanariot rulers highlights a series of their particular traits, which often merge in a predominantly stereotypical image, with political nuances nonetheless, whose main elements are: a good knowledge of several foreign languages, a superior culture, skilfulness in the political art and a superior knowledge and understanding of international relations. Alongside all these, two other defining traits that are a part of the larger spectre of Phanariot stereotypy can be added: cunningness and perfidiousness" (p. 43). Greediness, corruption or excessive bureaucratisation emerge as characteristics of the Phanariot regime particularly in Russians' notes, but are also present in Northerners' writings.

7 Ironically enough given that most Phanariot rulers were of Greek origin, the term "governance" is derived from a Greek word, namely "kubernân", which means "to rule", "to lead" or "to steer a ship" and it was used by Plato in relation to designing a governing system, particularly as, at first, the terms "governance" and "governing" were synonymous, the former receiving connotations concerning other actors than the state only during the $20^{\text {th }}$ century. Within this context, "good governance" and, implicitly, "bad governance" were defined in the 1990s by the World Bank with reference to the administration of money lent to Third World countries. For more terminological details see Anne Mette Kjær, Guvernanța (Cluj-Napoca: CA Publishing, 2010), pp. 1-3 and Alina Sorina Drăgan, Frontiere, guvernanță şi organizare politică. Regiunile ultraperiferice şi țările şi teritoriile de peste mări, Ph.D. Thesis (ClujNapoca: Faculty of History and Philosophy, 2015), pp. 20-23.

8 By "bureaucratisation" I refer to "an excessive appeal to procedures, lack of efficiency, unreadiness, the refusal to take decisions, excessive personnel, etc."; Liviu Radu, Guvernanță comparată (Bucharest: Tritonic Books, 2013), p. 79. 
past realities. ${ }^{9}$ In fact, discussing the Phanariot regime in terms of governance could be considered one of the elements of originality characterising this study, which consequently aligns Romanian historiographical works with foreign ones. Moreover, the thorough analysis of the sources, including some of the travellers' ulterior motives for conveying a certain image of the political system applied in the Romanian Principalities, represents another distinguishing feature of this study. Although the overall picture of the Phanariots that stems from travel accounts is not surprising for researchers familiarised with the topic, an analysis that focuses strictly on Russian and Nordic sources represents a novel approach to the subject.

\section{Sources}

The present paper is based on the notes of Nordic and Russian travellers who have passed through the Romanian Principalities in the $18^{\text {th }}$ $19^{\text {th }}$ centuries. Apart from their unmatched value as contemporary testimonies of past social and political realities, these sources also entail a number of problems, particularly given that often the boundaries between truth and fiction can only be established with great difficulty. Moreover, many travellers resorted to exaggerations in order to create literary effects

\footnotetext{
${ }^{9}$ In this sense examples abound and a simple bibliographical search in international databases reveals that historians extensively use this concept: Ritu Birla, Stages of Capital: Law, Culture and Market Governance in Late Colonial India (Durham, N.C.: Duke University Press, 2009); Tom Crook, 'Sanitary inspection and the public sphere in late Victorian and Edwardian Britain: a case study in liberal governance', Social History, Vol. 32, No. 4 (2007): 369-393; Laura F. Edwards, 'Status without Rights: African Americans and the Tangled History of Law and Governance in the Nineteenth-Century U.S. South', American Historical Review, Vol. 112, No. 2 (2007): 366-393; Tolga U. Esmer, 'Economies of Violence, Banditry and Governance in the Ottoman Empire Around 1800', Past and Present, Vol. 224, Issue 1 (2014): 163-199; Stefan Gaarsmand Jacobsen, 'Limits to Despotism: Idealizations of Chinese Governance and Legitimizations of Absolutist Europe', Journal of Early Modern History, Vol. 17 (2013): 347-389; Alan Lester, Fae Dussart, Colonization and the Origins of Humanitarian Governance: Protecting Aborigines across the Nineteenth-Century British Empire (Cambridge and New York: Cambridge University Press, 2014); Alistair Mutch, "To bring the work to greater perfection": Systematising Governance in the Church of Scotland, 1696-1800', The Scottish Historical Review, Vol. XCIII, 2, No. 237 (2014): 240-261; James Owen, 'Exporting the Westminster model: MPs and Colonial Governance in the Victorian era', Britain and the World, Vol. 7, No. 1 (2014): 2855; Gabriel B. Paquette, Enlightenment, Governance, and Reform in Spain and Its Empire, 17591808 (New York: Palgrave Macmillan, 2008); Michael Shurkin, ‘French Liberal Governance and the Emancipation of Algeria's Jews', French Historical Studies, Vol. 33, No. 2 (2010): 259280.
} 
and they were not always objective (and/or they did not intend to be objective) when they were describing certain realities.

Beyond these general observations, the peculiarities associated with the visits of Nordic and Russian travellers in the Romanian area also pose some issues. In this sense it must be mentioned that Northerners' interests in the area were almost irrelevant during the Phanariot period, whilst Russians were much more involved in the power struggles that took place above Romanians' heads. One of the direct consequences of this state of affairs is that Nordic travellers are relatively infrequent, which stands in stark contrast to the constant Russian presence on Romanian soil, the latter being mostly due to the recurrent military conflicts between the Tsar and the Sultan. Moreover, whilst Northerners' writings give a clear impression of objectivity (or, at least, of the authors' intention of presenting objective opinions), most Russian accounts provide obvious clues as to some (barely) hidden interests that shaped the story and how it was told. Consequently, Russian travellers are not only more numerous, but they also seem more prone to make political comments than Nordic ones.

The statements sketched above are clearly supported by the distribution of this article's sources. Thus, Russian travellers provide approximately $79 \%$ of the accounts that served as a foundation for this study, most of the Tsar's subjects being officers in the army (roughly 45\%) or diplomats (around 36\%). Two thirds of the Nordic travellers were also army officers, whilst the liberal professions were also represented, but to a lesser extent, for both Northerners and Russians (roughly 33\% and 18\%, respectively). As for the accuracy of the observations in terms of direct contact with the realities that were described, only half of the foreigners' visits took place prior to 1821 (with all of the Nordic voyages included in this category), whilst in the case of the other half of the journeys travellers could compare what they found out about the previous political regime with the subsequent evolutions (for example, the period when General Kiseleff's was governor of the Romanian Principalities). The graphs below summarise the sources' main characteristics. 


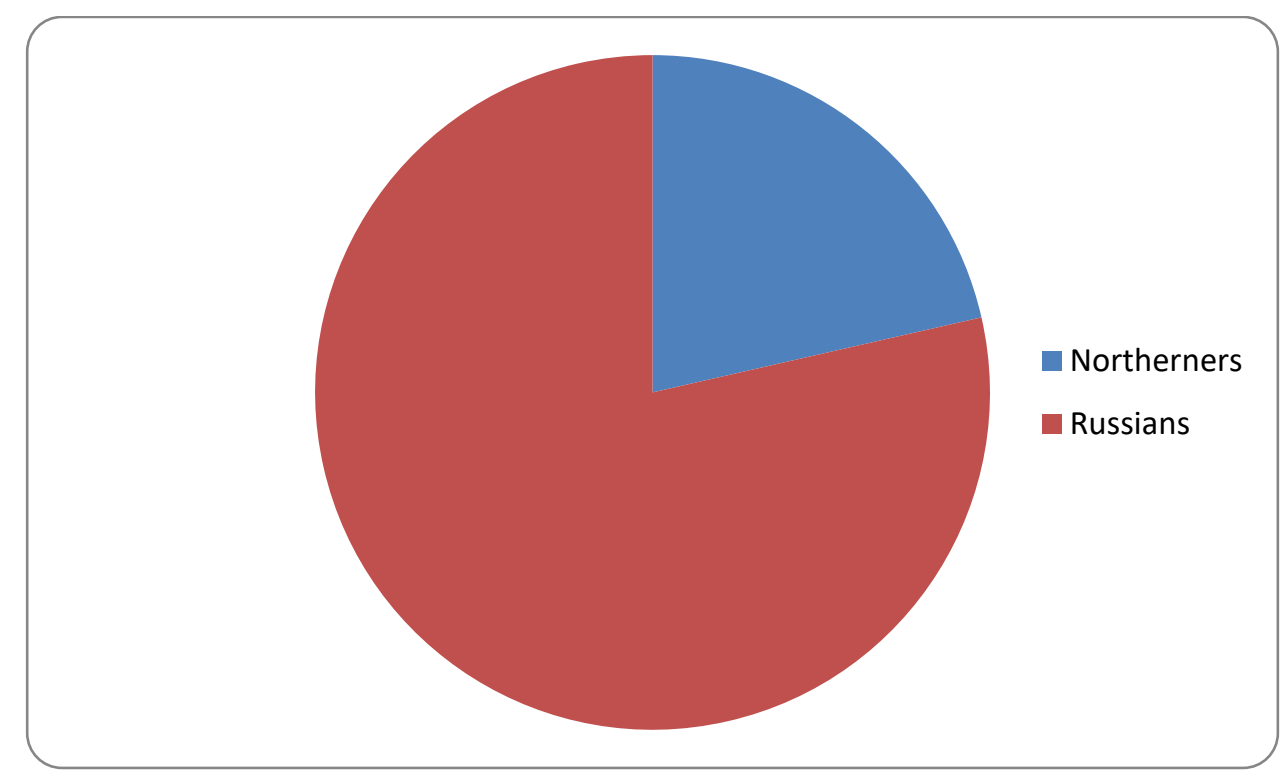

Figure 1: Distribution of accounts according to their author's origin

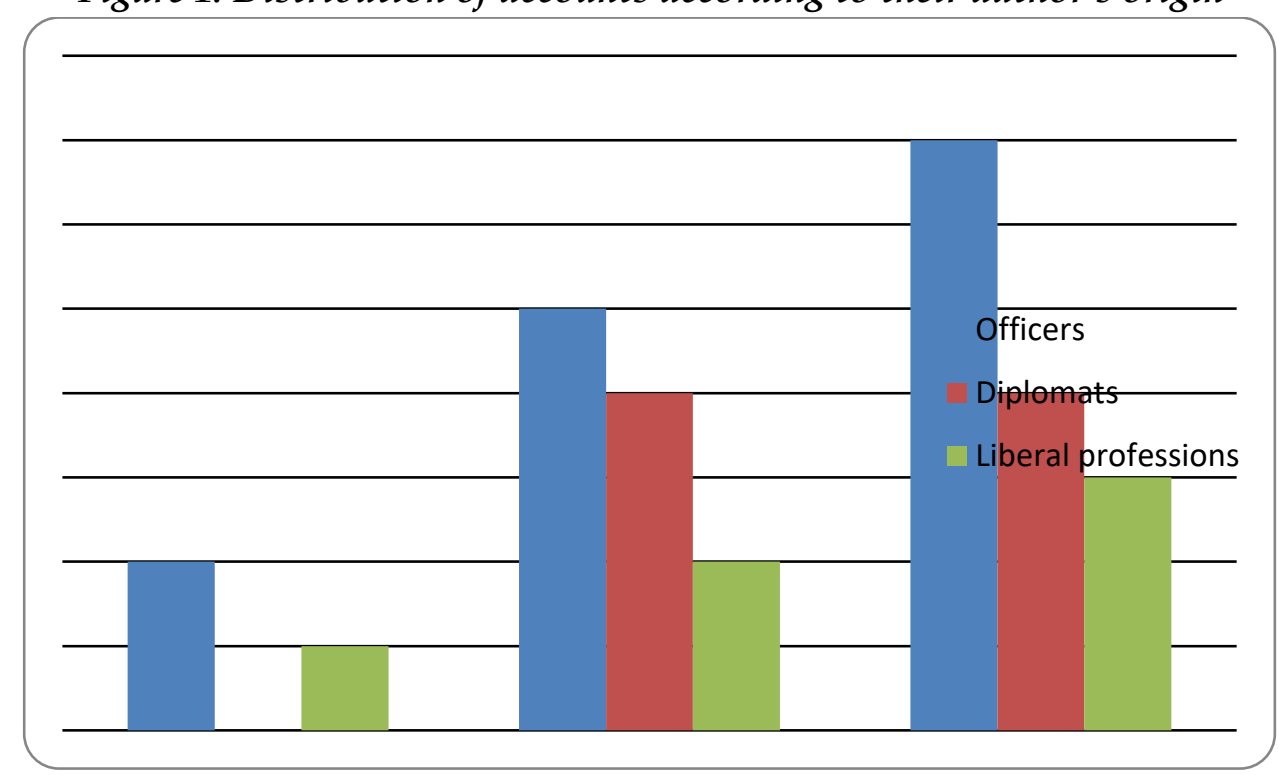

Figure 2: Distribution of accounts according to their author's occupation 


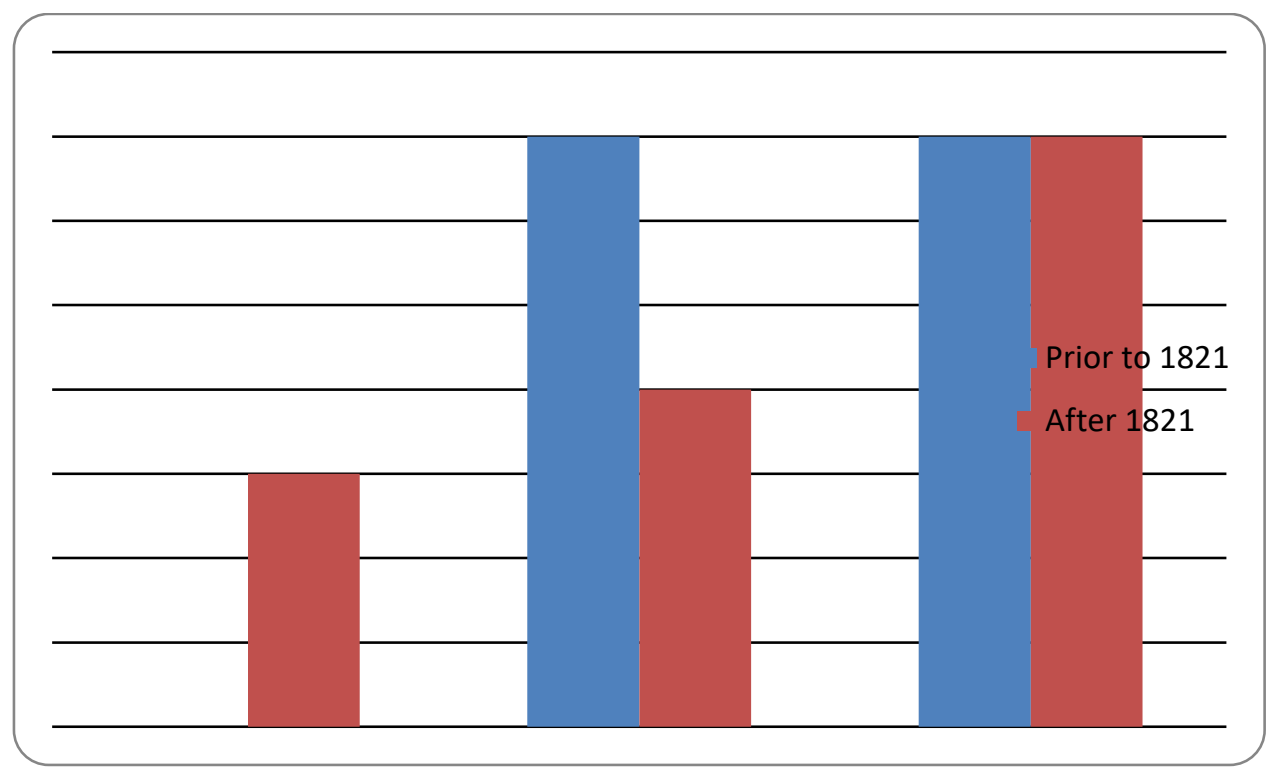

Figure 3: Distribution of accounts according to the chronological interval

\section{Images of the political regime from Moldavia and Wallachia between 1711/1716 and 1821}

Foreign travellers' opinions on the Phanariot regime were mostly negative, some of voyagers being extremely keen on emphasising all the problems associated with the rulers' manner of governing and with the Ottoman suzerainty over the Principalities. In this sense, they revealed a number of problems that directly affected the inhabitants' living conditions.

\section{Differences between the Principalities and Transylvania}

According to the testimony published in 1778 by the Russian officer of German origin Friedrich Wilhelm von Bauer, the continuous state of insecurity from Wallachia strengthened its already powerful connections with Transylvania, connections that were motivated by "the large similarities in land, habits and language". As a result, those who ran away from Wallachia because of the abuses that were inflicted upon them found a "new motherland" in the intra-Carpathian province, a motherland that had typically occidental political traits because the Transylvanian ruling system was "less subjected to violent changes with such fatal consequences". ${ }^{10}$

10 Călători străini despre Țările Române, Vol. X, part I, eds. Maria Holban, Maria M. Alexandrescu-Dersca Bulgaru, Paul Cernovodeanu (Bucharest: Editura Academiei Române, 2000), pp. 149-150. 


\title{
Differences between possibilities and realities
}

A rather objective image of the Principalities' situation during the Phanariot regime was provided by Louis-Alexandre Andrault de Langeron, who was convinced that Moldavia and Wallachia could be "Europe's heaven" if they were ruled by "a powerful prince or if they were inhabited by a diligent and hardworking people". But, sadly, history had been unfavourable to Wallachians and Moldavians and

\begin{abstract}
"the appalling state of these unfortunate countries, destroyed by wars, pillaged by victors, pillaged by those defeated, subjected to a regime that extinguishes any sap and any idea of activity and prosperity towards a better state, drained by rulers who seek only to enrich their families and whose limited and uncertain education and authority neither presuppose nor permit any development of the spirit or of talents; the state of these countries - where the strictest minimum of life maintenance is enough for the ambition and perhaps the ignorance of the inhabitants - would need centuries of peace and work before nature could be aided by man's handiwork so that both would bring the results that < people> admire in France, England and in the countries favoured by the advantages of a good rule and the fortune of a longlasting peace" ${ }^{11}$
\end{abstract}

\section{Differences in time - worsening conditions}

After his second visit, unfolded approximately two decades after the first, namely between 1806 and 1812, the same Langeron harshly criticised the Wallachian boyars' venal nature, ${ }^{12}$ presenting it as a trait imported from the Orient and using such terms as "excessive immorality", "heinousness", attitudes that were "repulsive to humankind", the boyars being "vile", "greedy", "cruel", "slavish towards the Turks", while "the notions of order, justice, honesty, honour are often forgotten in Wallachia. All offices are bought, meaning that you pay the right to commit any crime without being punished". The government was "monstrous", the high officials displayed "a luxury that is as impudent as it is tacky" and the "plundering, thefts, [and]

11 Călători străini despre Țările Române, Vol. X, part II, eds. Maria Holban, Maria M. Alexandrescu-Dersca Bulgaru, Paul Cernovodeanu (Bucharest: Editura Academiei Române, 2001), pp. 942-943 (hereinafter Călători străini..., Vol. X, part II).

12 The main characteristics of the boyar class during the Phanariot regime were presented by Zaharia 2012, pp. 21-26. 
cruelty of the Romanian high officials are neither hidden nor justified by a certain pretext". Even the chief of police in Bucharest was sometimes "the protector of thieves, the concealer of thefts", whilst "judges or chancellors provoke both civil and penal lawsuits or accuse of a crime those who are rich, in order to strip them [of their possessions]". ${ }^{13}$

In 1827-1831, Ivan Petrovici Liprandi also affirmed that "the one who does not know the Moldavians and the Wallachians will never be able to have an image of the intrigues, schemes and cunning that are plotted on such occasions", 14 considering that after "more than two months at Jassy, I had the opportunity to observe the spirit of cunningness, intrigue, haughtiness and vileness of the majority of boyars. Their inconstancy in the present circumstances is unimaginable". ${ }^{15}$ In fact, this emphasis placed upon the duplicitous behaviour of the elite ${ }^{16}$ only confirmed the high degree of political instability in the Principalities and, within this context, although we can comprehend the Russian officer's frustration, we also need to take into account the fact that the Russians were also not always defined by correctness and transparency in their actions.

Blaming the Turks

In this sense, the Russian officer of French origin Langeron admitted that some of the Russian functionaries were corrupted, but he laid all the blame for this situation on the Turks, whilst also giving examples of honest boyars and stating that Romanians had the potential of being civilised. Thus, "the imputations that I'm knowingly making to their morality cannot be addressed to all without exception", because "I have met amongst them very estimable, very delicate, very correct people, in low numbers[,] that is true, but nonetheless sufficient to save Nineveh. In fact, I would rather accuse the

13 Călători străini despre Țările Române în secolul al XIX-lea, New Series, Vol. I (1801-1821), ed. Paul Cernovodeanu (Bucharest: Editura Academiei Române, 2004), pp. 335-336 (hereinafter Călători străini..., New Series, Vol. I).

14 Călători străini despre T,ările Române în secolul al XIX-lea, New Series, Vol. II (1822-1830), eds. Paul Cernovodeanu, Daniela Buşă (Bucharest: Editura Academiei Române, 2005), p. 301 (hereinafter Călători străini..., New Series, Vol. II).

15 Gheorghe Bezviconi, Călători ruşi în Moldova şi Muntenia (Bucharest: Monitorul Oficial şi Imprimeriile Statului. Imprimeria Națională, 1947), p. 261. Zaharia 2012, pp. 24-25 states that the boyars' main characteristics during the Phanariot regime were vanity, laziness and disquietude, the latter being motivated by the extremely unstable political situation.

16 See Daniel David, Psihologia poporului român. Profilul psihologic al românilor într-o monografie cognitiv-experimentală (Jassy: Polirom, 2015), p. 40 where the author summarises the opinions of Dumitru Drăghicescu who asserted, amongst other things, that the Phanariot rulers played a very important part in accentuating Romanians' duplicity and cunningness. 
venal, oppressive and barbarous government under which the two countries, Moldavia and Wallachia, are moaning of the inhabitants' immorality than the latter's own inclinations. The boyars are sooner pitiful than blameable". ${ }^{17}$ The Ottomans were the ones culpable for a "stupid and atrocious" despotism that prevented Romanians from "being entirely different from how they are" because "in general they have spirit, qualities for businesses, they are good, gentle, even too shy, which also has to be attributed to the fear of the Turkish sword that they always see hanging above their heads".

\section{The underlying causes of political instability}

Frequent wars

Johann Christian von Struve, a Russian subject of foreign (presumably German) origin, reached a conclusion that was rather favourable to the Romanians after he had repeatedly travelled in the area between 1791 and 1794, namely that the diligence of Moldavians from Galati could bring them prosperity, "if a new destructive war will not put an end to the development of the small town once again". The same negative effects of military conflicts on the province's thriving were also remarked by the Russian traveller around Vaslui, given that "Moldavians cultivate their lands very well everywhere around here and of course they would do it even more if they were not driven out by the destructive wars". ${ }^{18}$ The diplomat seemed extremely convinced of this interpretation of the situation, noting on several occasions that "the activity of good Moldavians" consisting in "vineyards, cultivated fields and pastures" was worthy of being admired, but that, unfortunately, "the country is alternatively devastated due to the Porte's sad policy and by the bloody wars". However, the "good and fertile land", as well as the large number of "rivers and streams" repaid the inhabitants' efforts in cultivating the land to such an extent that "even after only three years of peace villages and towns are revived again". ${ }^{19}$

\footnotetext{
17 Călători străini..., New Series, Vol. I, p. 337.

18 Călători străini..., Vol. X, part II, pp. 1135, 1137. Indeed, during the $18^{\text {th }}$ century, "In case of war with its cortege of plunder, enslavement (by the Tatar troops especially) and forced contributions, the flight took mass proportions endangering the entire system of production and taxation"; Mihai Olaru, 'From Local Custom to Written Law. Agrarian Regulations and Infrastructural Growth in Wallachia, 1740-1800', Studia Universitatis Babeş-Bolyai, Historia, Vol. 58, No. 1 (2013): 163.

19 Călători străini..., Vol. X, part II, pp. 1140-1141.
} 
Heinrich von Reimers supported this view as he considered that "Moldavia is a beautiful country which, although it was a theatre of war and the apple of discord for its neighbours several times during past centuries, as it is also nowadays, it nevertheless recovered rapidly from its sufferings and the fertile and rich land is generally well cultivated. How many times hasn't it been the case that the cannons' peal drove away the peaceful storks from their nests, storks whom have built here, in large numbers, their nests on the chimneys of peasant houses, and that it also drove them [the peasants] out of their tranquil homes". ${ }^{20}$

\title{
Ottoman suzerainty
}

Unfortunately, the system of Phanariot rule with all its negative traits prevented any improvement in Moldavia's situation, because as von Struve observed:

\begin{abstract}
“the country would amend itself very easily if it wasn't the theatre of war all the time and if peace and tranquillity would reign more in it. But as the ruler, so to say, is not ensured of preserving his rule not even for one day, his policy, so harmful for the country, consists only in burdens and dues in order to support himself with the money extorted from the inhabitants even when he will have ceased being a ruler. Most of the times the Porte's dragomans are raised to this office that is conferred to the ones that offer the most" ${ }^{21}$
\end{abstract}

Dimitri Bantâş-Kamenski also described the system by which rulers were appointed and revoked, the reasons that motivated them to oppress the population, as well as the most frequent end result of their career. ${ }^{22}$ Thus he revealed that "the rulers were chosen from amongst the most notable Greek families", "each of them, in their desire to get this position, accumulated large debts, in order to bribe the greedy Turkish high officials" and then they

\footnotetext{
20 Călători străini..., Vol. X, part II, pp. 1162-1163.

${ }^{21}$ Călători străini..., Vol. X, part II, pp. 1140-1141. Indeed, most Phanariot rulers had acted as dragomans before being appointed as princes of the Romanian Principalities, this being the "highest office that could be occupied by Christians in the period's Turkish political system"; Tipău 2004, p. 8. This implied that they pertained to highly cultivated environments and that they spoke well a number of different foreign languages.

${ }^{22}$ A summary of the Phanariot regime's manner of functioning that is strikingly similar to that provided by the Russian traveller is available in Zaharia 2012, p. 100.
} 
habitually occupied the throne for "a very short timespan, two-three, at the most five years", 23 a period during which

"they sought to enrich themselves from the dues collected from the population. In this manner, they succeeded not only in paying their debts, but they also in returning with millions to Constantinople, where they attempted to seem very poor, for fear of being robbed by the same Turkish ministers to whom they owed everything. Often even the Sultan killed these rulers, ${ }^{24}$ in order to take possession of their wealth over which he, according to the laws from these countries, has an incontestable right. This right extends even over the highest Turkish officials, even over the vizier himself" ${ }^{\prime 25}$

\section{Phanariot rulers}

Vasile Ivanovici Kelsiev was even more incisive in his (retrospective) ${ }^{26}$ appreciations, the manner in which he described the Phanariots leaving no doubt about his opinions:

"this crossbreed of Greeks, whom the Greeks themselves hate, the Phanariots[,] ruled Moldavia in the past. You must see these people to understand through what they drew so much hatred upon themselves. They have no patriotic sentiment, no political principle and in general no aspirations that any man has. They sacrifice all for money, for a career; they sell not only their daughter, but also their wife and they can denounce their own brother for this. Amongst them there are people who have learned a thing or two, which is for the worst; the fact that they know how to keep alive a conversation in society, cognizance of foreign languages, knowledge and talents are not used in other purposes than to increase their incomes, to make their way in life. The Turks' spies are Phanariots. The secretaries of the governors for

\footnotetext{
${ }^{23}$ During a century, namely between 1711/1716 and 1821, Moldavia and Wallachia were ruled by 31 princes belonging to 11 families. Some of these rulers occupied one or both of these thrones several times, the record being set by Constantine Mavrocordatos, who had 10 separate reigns in both Principalities (6 in Wallachia and 4 in Moldavia) totalising 20 years and one month between 1730 and 1769. More details on this topic are available in Tipău 2004, pp. 15-16.

${ }^{24}$ In fact, only three Phanariot rulers were murdered by order of the Sultan whilst they were still on the throne; Tipău 2004, p. 16.

${ }_{25}$ Călători străini..., New Series, Vol. I, p. 404.

${ }^{26}$ He visited the Romanian area in 1867 and thus his notes were not based on direct observations, but merely on information gathered from other sources.
} 
connections with the foreign consulates are Phanariots. The political agents are half Phanariots". ${ }^{27}$

The accuracy of these representations characterising the Phanariot regime is worthy of note, although it is clear that we cannot attribute only altruistic reasons to their authors for revealing these political realities. The details provided, corroborated with allusions to Romanians' Orthodox faith and with descriptions of the Principalities' natural riches were probably meant, consciously or unconsciously, to motivate the anti-Ottoman Russian actions that were unfolding based on political, but also economic, religious and even humanitarian grounds.

\title{
Positive traits of the Phanariot regime
}

Johan Hedenborg remarked several favourable effects of the Phanariot regime, given that some of the rulers adopted reforms that were beneficial to the Romanian area. ${ }^{28}$ The example provided by the Swedish physician is that of Nicholas Mavrocordatos, ruler of Wallachia beginning with 1716, identified by the foreign traveller as "the first Greek who had attained this office", namely that of "hospodar". From Hedenborg's viewpoint, the cultural progress achieved during that period was major, as

\begin{abstract}
"Moldavia and Wallachia were at that time bare of any culture and civilisation, nine tenths of the land remaining uncultivated. The Greek hospodars have introduced instruction and culture into the country. Mavrocordatos was the founder of a printing house and of a school where the Old Church Slavonic language, old Greek and Latin were taught. ${ }^{29}$ His brother, Constantine, liberated the peasants from
\end{abstract}

\footnotetext{
27 Bezviconi 1947, p. 413.

28 A series of reforms with modernising effects in organising and storing administrative information promulgated by the Phanariots were thoroughly analysed by Vasile Mihai Olaru, '"Trecut în condică". Stocarea informației şi puterea statală în Țara Românească în secolul al XVIII-lea', Revista istorică, Tome XXV, No. 3-4 (2014): 323-348, two of the conclusions of his research being that these administrative improvements had as an effect the fact that the state started to be perceived as "an objective entity, both ontologically and morally" (p. 342) and that "during the second half of the $18^{\text {th }}$ century the state has extended to a certain extent its infrastructural capacity, namely the capacity of acting at a distance and of imposing its will in the territory" (p. 347).

${ }^{29}$ Information about the Phanariot rulers' contribution to the development of education in various manners is available in Zaharia 2012.
} 
bondage ${ }^{30}$ and introduced maize (sic), which has now become the inhabitants' most important aliment. The following hospodars ordered the translation of the Bible in the country's language, as well as the churchly books from the Greek language. They also promulgated printed codes of law". 31

Apart from adopting a number of reforms and supporting cultural advancement at large, Phanariot rulers manifested a general attitude of openness towards innovation ${ }^{32}$ as demonstrated by an original observation pertaining to Leyon Pierce Balthasar von Campenhausen. This note that also

30 More details about Constantine Mavrocordatos' agrarian reform are available in Olaru 2013, pp. 155-180. The author argues that "By the agrarian regulations, the state becomes the third party arbitrating between landlords and tenants and it acquires the character of a necessary and 'real' entity" (p. 158). Moreover, "In 1741, Constantin Mavrocordat issued a large charter of reorganization in several domains (fiscal, judicial-administrative, social)." (p. 165). On the other hand, Zaharia 2012, pp. 34-35 considers that "Constantine Mavrocordatos' reform had as a consequence the suppression of all the real advantages that the peasant enjoyed before 1746 and the transformation of the peasant into a taxpayer [...]. Now the landlords no longer have any obligation towards the peasant. Therefore the liberation of $1746-1749$ was in reality nothing more than the liberation of boyars from most of the obligations towards the peasant, on the one hand, and, on the other hand, towards the state. As for the peasant, instead of one master he now has two: his old landlord and the State". Tipău 2004, pp. 22-24 also mentions Constantine Mavrocordatos "reorganisation" of the fiscal, administrative and institutional areas revealing that the Phanariot ruler posed as an Enlightened monarch on these grounds. The connections between the Phanariot regime and Enlightenment in south-eastern Europe were revealed by Nicolae Isar, Principatele Române în epoca Luminilor (1770-1830). Cultura, spiritul critic, geneza ideii naționale, Second revised edition (Bucharest: Editura Universității din Bucureşti, 2005).

31 C. J. Caragea, 'Părerile unui suedez despre țara noastră pe la începutul secolului al XIX-lea', Revista Istorică: dări de seamă, documente şi notițe, VI, No. 1-2 (1920): 50. One of the Phanariot princes who issued an important code of law (in 1780) and implemented a series of fiscal, economic, administrative, juridical and educational reforms was Alexander Ypsilantis, who reigned for the first time in Wallachia between 1774 and 1782. Another Phanariot ruler who promulgated an important civil code was Scarlat Callimachi, whose third reign in Moldavia unfolded between 1812 and 1819. Details about these accomplishments are available in Tipău 2004, pp. 30 and 41, respectively. Alexander Ypsilantis' reforms were analysed by Nicolae Isar, Din istoria politică a Principatelor Române. De la fanarioți la domniile naționale (1774-1829) (Bucharest: Editura Universității din Bucureşti, 2008), pp. 39-41. The last-mentioned author also provides some details about Scarlat Callimachi's code of law (pp. 49-50). Moreover, the Phanariot rulers significantly contributed to the standardisation of measurements, as revealed by Vasile Mihai Olaru in two separate studies: "The "Juridist" Fallacy. Methodological Aspects of the Study of Weights and Measures in Romanian Historiography', Philobiblon. Transylvanian Journal of Multidisciplinary Research in the Humanities, Vol. XX, No. 2 (2015a): 434446, and Olaru 2015b, pp. 200-220.

32 The fact that receptivity towards new ideas characterised most of the Phanariot rulers is also noted by Zaharia 2012, pp. 58-59. 
contains an indirect mention of Moldavia as a country belonging to the Occident referred to the fact that in the context of the Russo-Turkish war of 1787-1791 "the Turks have destroyed all the gardens and, especially, the only orangeries from Europe, which the ruler and the boyars possessed [and] where one could see orange, citron and laurel trees of an amazing height and thickness". ${ }^{33}$ Thus, the Phanariots could successfully adapt foreign models to local realities and these innovations were sometimes unmatched in the whole of Europe.

\title{
After the Phanariot regime - attempts at good governance
}

The period when Pavel Dimitrievici Kiseleff was governor of the Romanian Principalities, namely 1829-1834, the elaboration of the Organic Regulations and particularly the implementation of the measures stipulated by them had salutary effects on Romanians, at least in the opinion of the justmentioned Russian general. Hence, "the youth found means of education in its motherland's schools", 34 whilst

\begin{abstract}
"the internal civil governing system and the military administration receive a systematic development; the inhabitants' confidence increases; incomes from concessions and general ones increase; theft, which here is a local custom, decreases day by day and the lower class starts to breathe more easily. The town police and the disastrous quartering commissions are on the way to reorganisation; keeping the records in the treasury (minister of finances), hospitals and commissions are being organised in accordance with severe and uniform rules; sowing, done with the participation of the government, will be vast; the quarantine line on the Danube, being an important thing for Russia, is being organised with the utmost attention and the adequate intensity of action; the local militia will be formed and the reorganisation committee is working incessantly, although it would want to maintain the detrimental privileges of boyars, against which I am fighting as an accomplisher of the Emperor's will and Christian". ${ }^{35}$
\end{abstract}

\footnotetext{
33 Călători străini..., Vol. X, part II, p. 879.

34 Bezviconi 1947, p. 276.

35 Bezviconi 1947, pp. 289-290.
} 
Nevertheless, despite all these progresses which represented clear steps towards good governance, 36 "there is still much left to do for the one who will have to rule this country", because one practically needed "to reconstruct from top to bottom the entire edifice, on the way to crumbling, of the old institutions. But only in these conditions you could work effectively for the country's good state and internal tranquillity".

The steps to be taken towards this total remodelling are also noted by the Russian General:

"to precisely establish the rights and obligations for inhabitants of all [social] classes, to eliminate abuses, respecting the earned rights, to abolish compulsory work on boyars' plots and pay in kind, to simplify the collection of taxes, to organise the department of justice, by separating justice from administration, to found the gendarmerie for preserving internal order, to organise quarantines on the Danube and to give freedom to commerce". ${ }^{37}$

Russian interests: discourse and reality

On the other hand, it must be mentioned that, as an ardent patriot, Kiseleff admitted to his superiors that his true intention was "to earn [the Principalities'] wealth for Russia by means of trade and to submit Moldavians and Wallachians in the future, with the help of our education and by introducing our customs and mores". The General even set forth a number of concrete measures in this sense, so that, in the end, "without causing any commotion in Europe, without expenses for the maintenance of our armed forces in this country, we will have our border on the Danube, with local measures of protection against the plague". ${ }^{38}$

Nordic opinions and interpretations

In 1835, thus shortly after the end of Kiseleff's mandate as governor of the Romanian Principalities, Helmuth von Moltke, a Prussian officer of Danish stock, observed the manner in which some of the improvements envisaged by the Russian General were being put into practice. Although he overestimated the latter's role and he did not give sufficient consideration to

\footnotetext{
36 At the beginning of the $19^{\text {th }}$ century, governance comprised two elements: "political power, still represented by the sovereign[,] and the structure that was then strictly subordinated to him, public administration", a radical metamorphosis of these elements having occurred throughout the 18 th century; Radu 2013, pp. 24 and 29, respectively.

37 Bezviconi 1947, p. 303.

38 Bezviconi 1947, pp. 289-290.
} 
internal factors, von Moltke nevertheless acknowledged that Kiseleff's position provided him with a series of advantages in comparison to Romanian rulers and that a long period of time was still needed for the consolidation of these reforms and of their effects:

"the peasants freed, their dues diminished, the taxes limited and fixed, the postal service established, the defence lines against the plague drawn, the town's streets paved, 6,000 soldiers recruited and organised, almost all is due to the Russian occupation during the time of General Kiseleff. However, it is also fair to recognise that the Russian General had the power to do many things that the Romanian ruler cannot attempt; on the other hand, the time gone by is too short so that the situation of a country, which was tried for so long and so cruelly, to improve in a satisfying manner". 39

\section{The aftermath of the Phanariot regime - persisting shortcomings}

The fact that some defects of the Phanariot rule lingered on at least until the second half of the $19^{\text {th }}$ century (although one might find enough arguments to assert that they are still present today in Romanian politicians' behaviour) was certified by Grigore Petrovici Danielevschi. The Russian writer was informed by politician Nicolae Golescu of a number of abuses and corruption acts that had taken place during the reign of Alexandru Ioan Cuza (1859-1866):

"when we took the helm of governing in our hands and we stayed in power for three full months, we realised how much the treasury had been sacked. A lackey from Moldavia, waiter at several hotels, a certain Liebrecht (you've probably heard this name), became, in five years, unexpectedly, first telegraph inspector, afterwards, out of the blue, director of the post and telegraph [system] and, in the end, all the cabinet businesses of the ruler were passed to him. No one could obtain without him an auction or a place and, all of a sudden, Liebrecht became the owner of one of the richest houses in Bucharest, with furniture from Paris, with silks from Lyon, with bronzes from London and with four million piasters in cash... We arrested him and sued him.

\footnotetext{
39 Călători străini despre Țările Române în secolul al XIX-lea, New Series, Vol. III (1831-1840), eds. Paul Cernovodeanu, Daniela Buşă (Bucharest: Editura Academiei Române, 2006), pp. 379-380 (hereinafter Călători străini..., New Series, Vol. III).
} 
Now we are also suing - because of him - Cuza's ministers, Florescu and Kretzulescu..." 40

The ways in which mores, both from the private sphere and those pertaining to the public arena, were affected by the Principalities' tumultuous history was commented upon in a rather pertinent manner by Vasile Ivanovici Kelsiev. The Russian publicist observed that

\begin{abstract}
"the centuries-old habit of being under foreign rule had as an effect the atrophy of patriotic sentiments in the masses here and made them very materialistic. Greeks, Bulgarians and Serbians do not manifest the same indifference towards their country's fate. They had a single enemy - the Turks and their helpers - the Greeks. Turkey's peoples know well who their enemy is, that is why each of them seeks to unite in a single country, each having a ruler, which they hang on to as a child to his mother and therefore they are strong. With the Romanians the situation is different. A small people, positioned by fate between powerful neighbours, they willy-nilly had to yield - now to one, then to another, so that they have become accustomed to the thought that their fate does not depend upon them. Here ruled the Turks, and the Polish, and we have also intervened with our protectorate, ${ }^{41}$ and Austria also entered with an army through here... Finally, they were placed under the protectorate of Europe's great powers - meaning that they have become completely disorientated". 42
\end{abstract}

Within this context, it is worth mentioning that, although the political situation was not as bad as Kelsiev depicted it, some less occidental practices (if we can label them as such) persisted until the end of the 19th century, when the Swede traveller "Topchi" was extremely intrigued and sooner critical with regard to the seriousness of disputes, because "in the domain of domestic politics, there is always in Romania a fierce fight between the

\footnotetext{
40 Bezviconi 1947, p. 410.

41 The Russian protectorate over the Romanian Principalities was inaugurated through the peace treaty of Küçük-Kaynarca (1774), which stipulated, amongst other things, that Russia had the right to intervene in favour of the Christians inhabiting within the borders of the Ottoman Empire, that it had the right to establish consulates in Turkey and that the Porte's Russian subjects had the same privileges as those of other powers; Isar 2008, pp. 16-17.

42 Bezviconi 1947, p. 416. A summary of the Romanian Principalities' international status starting with the $16^{\text {th }}$ century and until the second half of the $19^{\text {th }}$ century is provided by Maxim 2013, pp. 54-56.
} 
government and the opposition, a fight that is perhaps more violent than anywhere else and which often leaves room to terrible scenes during elections". 43

Moreover, towards the end of the Phanariot regime, the Principalities still lacked a number of elements required in order to be considered occidental in terms of good governance. For example, Ignati Iakovenko was willing to include Wallachia amongst European states on condition that the natural resources were used in the state's benefit, because in such a manner "the care of a well-intentioned government and a small amount of support granted from its part could bring the Principality of Wallachia amongst the greatest and most flourishing regions of Europe". ${ }^{44}$

However, a decade later, Ivan Petrovici Liprandi considered that Moldavia and Wallachia were not ready to be European because

"in a well-organised state common good is placed above personal advantages, but this will not be the case of the Romanian Principalities, which have not yet matured and are not ready to receive an administration of a European type. With all its advantages, it would be more oppressive and unbearable, especially for the lower classes, than some of the boyars' arbitrary actions". ${ }^{45}$

Within this context, the Organic Regulation is not only "deficient in many respects, but it surpasses the country's cultural level and nobody can understand the good that it brings", the main reason for this situation being that "the future is not taken into consideration, only the present serves as a basis for everything and the past, with all the miseries suffered, is considered a time of welfare". Moreover,

"where no [social] class is sufficiently mature to receive a European institution, no matter how favourable it would be[,] and where the power of a single person is still necessary for a long time to come for the preservation of general tranquillity[,] [...] on such a land it is difficult, and without exceptional efforts almost impossible, to implant such an institution and even harder for it to take roots". ${ }^{46}$

\footnotetext{
43 Aurel George Stino, 'Un călător suedez despre România vremurilor', Păstorul Tutovei. Revista Asociației preoților din județul Tutova, No. 1-4 (1943): 8-9.

${ }^{44}$ Călători străini..., New Series, Vol. I, p. 848.

45 Călători străini..., New Series, Vol. II, p. 300.

46 Călători străini..., New Series, Vol. II, p. 310.
} 


\section{Concluding remarks}

The Phanariot regime was perceived in an extremely negative manner by almost all foreign travellers ${ }^{47}$ and if we broadly define governance as "the establishment, application and implementation of rules" 48 it becomes obvious that it is impossible to speak about good governance during the Phanariot period. Moreover, other fundamental traits of good governance were also absent, particularly as the rulers' legitimacy was derived neither from democracy, nor from efficiency, ${ }^{49}$ but merely from the Sultan's will (and from the amounts of money that filled his coffers), whilst several elements characterising weak or failed states were present, as, for example, the fact that the regime could not adequately provide political goods such as peace, security, law and order or certain social or economic goods such as development and prosperity. ${ }^{50}$

This outstanding example of bad governance survived for more than a century not only because the Porte had a direct interest in the persistence of this state of affairs, but also because the Phanariots acted as an interest group, namely "a more or less organised association of individuals who have common interests and who attempt, through specific means, to influence the decisions of the authorities in the sense of attaining those interests", 51 the authorities being here represented by the Ottomans. Unfortunately for the

\footnotetext{
47 Some Romanian historians were also critical with regard to the Phanariot rulers, but an evolution towards a more balanced view of this period is discernible, as Olaru 2013, pp. 160161 notices when reviewing "the (mostly) Romanian literature on the Phanariots which sees the period of the 'Greek' rulers as - at best - a period of crisis marked by well-intended but ultimately failed reforms and at worst [as] the source of Romania's belated and incomplete modernization. It is true that from the late $19^{\text {th }}$ century the negative image of the Phanariot period underwent a sustained critique and the modernizing tendencies of the Phanariot rule was highlighted; but in the first case the deconstruction targeted the inconsistencies of the anti-Phanariot stereotypes while in the second the insights were never studied systematically. Such accounts usually looked at the administrative (under)achievements of the Phanariot state, namely to its impact upon the living conditions of the population. The almost general picture was that of a corrupt and abusive administration which plundered the subject population, debilitating its productive capacities. As I show in this paper, by shifting the perspective and looking at how the state regulated the agrarian relations, it is possible to observe crucial processes whereby the modern state, both as 'state-system' and as 'state-idea' comes into being".

48 Kjær 2010, p. 10.

${ }^{49}$ Kjær 2010, p. 12.

50 Kjær 2010, p. 145.

51 Radu 2013, p. 59.
} 
Romanians, these selfish interests did not coincide with those of the community, which resulted in an excessively unstable political regime defined by a very ineffective manner of using the available resources, by utter, pervasive and inescapable corruption and by complete disregard towards the welfare of the society at large.

The causes of this wretched situation were clearly identified by the travellers: frequent wars unfolding on the Principalities' territory and Ottoman suzerainty manifested in the form of Phanariot rulers. Habitually, Russian voyagers are the ones commenting upon the negative political realities encountered in the Principalities during the $18^{\text {th }}-19^{\text {th }}$ centuries, due to the international context. Namely, the almost incessant state of war with the Ottoman Empire brought them in large numbers in this area and motivated them to be attentive to the regime (if this was not an explicit workrelated task). Moreover, their interests entailed careful consideration with regard to rulers and Ottoman suzerainty and, as Kiseleff clearly demonstrated, their sympathy towards the peasants, for example, was by no means altruistic. Besides all this and although the only assessment of the Phanariot regime that also emphasised its positive outcomes belonged to a Northerner, we should not minimise, disregard or consider that Russians' accounts were false. On the contrary, their observations are usually correct and detailed, even if sometimes there is a clear tendency towards exaggeration.

Consequently, the image depicted mostly by Russian officers and diplomats differs from the notes provided by Nordic voyagers, who seem more objective and more keen on noticing the positive aspects of the political system from Moldavia and Wallachia between 1711/1716 and 1821. Overall, the general conclusion that results from all these reports is that the chance for good governance offered by the return to rulers appointed from amongst the local elite (1821-1829), as well as by the period when Pavel Dimitrievici Kiseleff acted as governor of the Principalities (1829-1834) was only partially capitalised upon, as the improvements enforced were not based on ethical and morally-sound bases, this being one of the explicative factors of the longlasting adverse effects of the Phanariot regime on Romanian politics. 


\section{References:}

\section{Travel literature}

Bezviconi, Gheorghe. Călători ruşi în Moldova şi Muntenia. Bucharest: Monitorul Oficial şi Imprimeriile Statului. Imprimeria Națională, 1947.

Caragea, C. J. 'Părerile unui suedez despre țara noastră pe la începutul secolului al XIX-lea'. Revista Istorică: dări de seamă, documente şi notițe, VI, No. 1-2 (1920): 49-52.

Călători străini despre Țările Române în secolul al XIX-lea, New Series, Vol. I (1801-1821). Ed. Paul Cernovodeanu. Bucharest: Editura Academiei Române, 2004.

Călători străini despre Țările Române în secolul al XIX-lea, New Series, Vol. II (1822-1830). Eds. Paul Cernovodeanu, Daniela Buşă. Bucharest: Editura Academiei Române, 2005.

Călători străini despre Țările Române în secolul al XIX-lea, New Series, Vol. III (1831-1840). Eds. Paul Cernovodeanu, Daniela Buşă. Bucharest: Editura Academiei Române, 2006.

Călători străini despre Țările Române, Vol. X, part I. Eds. Maria Holban, Maria

M. Alexandrescu-Dersca Bulgaru, Paul Cernovodeanu. Bucharest: Editura Academiei Române, 2000.

Călători străini despre Țările Române, Vol. X, part II. Eds. Maria Holban, Maria M. Alexandrescu-Dersca Bulgaru, Paul Cernovodeanu. Bucharest: Editura Academiei Române, 2001.

Stino, Aurel George. 'Un călător suedez despre România vremurilor'. Păstorul Tutovei. Revista Asociației preoților din județul Tutova, No. 1-4 (1943): 8-12.

\section{Secondary sources}

David, Daniel. Psihologia poporului român. Profilul psihologic al românilor într-o monografie cognitiv-experimentală. Jassy: Polirom, 2015.

Drăgan, Alina Sorina. Frontiere, guvernanță şi organizare politică. Regiunile ultraperiferice şi țările şi teritoriile de peste mări, Ph.D. Thesis. ClujNapoca: Faculty of History and Philosophy, 2015.

Isar, Nicolae. Din istoria politică a Principatelor Române. De la fanarioți la domniile naționale (1774-1829). Bucharest: Editura Universității din Bucureşti, 2008. 
Isar, Nicolae. Principatele Române în epoca Luminilor (1770-1830). Cultura, spiritul critic, geneza ideii naționale, Second revised edition. Bucharest: Editura Universității din Bucureşti, 2005.

Kjær, Anne Mette. Guvernanța. Cluj-Napoca: CA Publishing, 2010.

Maxim, Mihai. $O$ istorie a relațiilor româno-otomane, $\mathrm{cu}$ documente noi din arhivele turceşti. Vol. II: De la Mihai Viteazul la fanarioți (16011711/1716). Brăila: Editura Istros a Muzeului Brăilei, 2013.

Olaru, Mihai. 'From Local Custom to Written Law. Agrarian Regulations and Infrastructural Growth in Wallachia, 1740-1800'. Studia Universitatis BabeşBolyai, Historia, Vol. 58, No. 1 (2013): 155-180.

Olaru, Vasile Mihai. '"Trecut în condică”. Stocarea informației şi puterea statală în T,ara Românească în secolul al XVIII-lea'. Revista istorică, Tome XXV, No. 3-4 (2014): 323-348.

Olaru, Vasile Mihai. "The "Juridist" Fallacy. Methodological Aspects of the Study of Weights and Measures in Romanian Historiography'. Philobiblon. Transylvanian Journal of Multidisciplinary Research in the Humanities, Vol. XX, No. 2 (2015a): 434-446.

Olaru, Vasile-Mihai. 'The Princely Fathom. Uniformization of Measures and State Making in Wallachia, 1775-1831'. Studia Universitatis BabeşBolyai, Historia, Vol. 60, No. 1 (2015b): 200-220.

Popescu, Liviu. "Imaginea regimului politic în Principate. De la fanarioți la mişcarea lui Tudor Vladimirescu". In Societatea românească între modern şi exotic văzută de călători străini (1800-1847). Eds. Ileana Căzan, Irina Gavrilă. Bucharest: Oscar Print, 2005, 27-92.

Radu, Liviu. Guvernanță comparată. Bucharest: Tritonic Books, 2013.

T,ipău, Mihai. Domnii fanarioți în Țările Române 1711-1821. Mică enciclopedie. Bucharest: Omonia, 2004.

Zaharia, Nicolae. Educație şi cultură în secolul fanariot. Câmpulung Muscel: Larisa, 2012. 